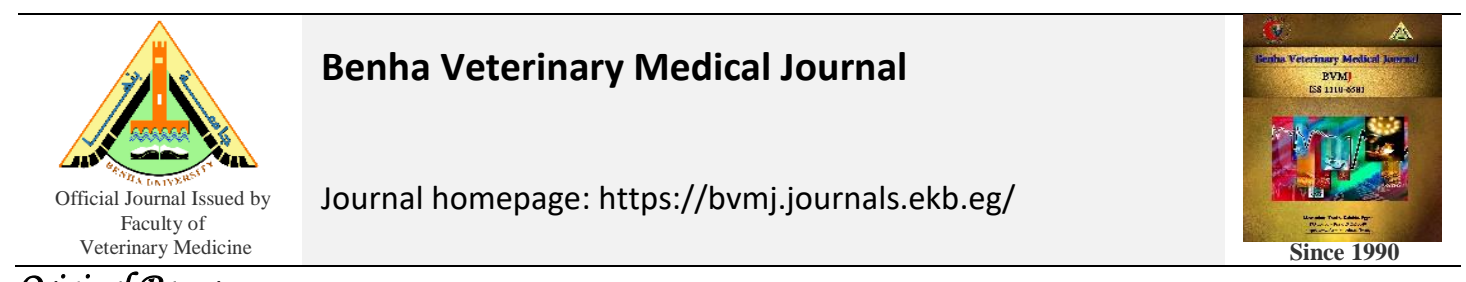

Original Paper

\title{
Diversity of some food borne fungi associated with raw milk and some cheese in Egypt
}

Ashraf A.Abd El Tawab ${ }^{1}$, Fatma I.El-Hofy ${ }^{1}$, Eman M. EL-diasty ${ }^{2}$, Ebtehal Abo-Hamdah ${ }^{2}$ and Manar AlKhayat $^{1}$

${ }^{1}$ Bacteriology, Immunology and Mycology Department, Faculty of Veterinary Medicine Benha University, Egypt

${ }^{2}$ Animal Health Research Institute, Dokki, Giza, Egypt.

\begin{tabular}{l} 
ARTICLE INFO \\
\hline Keywords \\
Cheese \\
Egypt \\
Moulds \\
Raw milk \\
Yeasts \\
\hline Received 23/02/2020 \\
Accepted 29/03/2020 \\
Availa6le On-Line \\
18/07/2020
\end{tabular}

\begin{abstract}
Contamination of milk and cheese with different types of fungi would constitute a public health hazard. These fungi may cause mycotoxicosis in human and/or spoilage of these products. This study aimed to the isolation and identification of mould and yeast in raw milk and some cheese. Sixty samples were collected from Giza Governorate, Egypt including; 20 raw milk, 20 processed cheese and 20 soft white cheese. The results reported that, overall incidence rate of moulds in processed cheese, soft white cheese and raw milk were; 18/20 (90\%), 6/20 (30\%) and $16 / 20(80 \%)$, respectively, while the mean mould counts were $1.3 \times 10^{3} \pm 1.8 \times 10^{2}$ cfu/g, $6.7 \times 10^{3} \pm 2.6 \times 10^{3} \mathrm{cfu} / \mathrm{g}$ and $5.9 \times 10^{3} \pm 1.3 \times 10^{3} \mathrm{cfu} / \mathrm{m}$, respectively. The isolated mould species from these samples were Aspergillus spp., Penicillium spp., Eupenicillium spp.,Phoma spp., Geotrichum spp.and Fusarium spp. Meanwhile, the yeast contamination was detected in soft white cheese and raw milk samples with incidence rate of 10/20 (50\%) and 16/20 (80\%), respectively, while not detected in processed cheese samples. The most predominant yeast species isolated from soft white cheese and raw milk samples were Debaryomyces hansenii, Pichia anomala, Sacharomyces cervisioe, Candida tropicalis, Candida pseudotropicalis, Torulopsis and Rhodotorula. In conclusion, the presence of high incidence of fungi in raw milk and cheese samples would lead to a public health hazards and/or economic losses due to spoilage of these products, therefore, strict hygienic conditions are required.
\end{abstract}

\section{INTRODUCTION}

Raw milk and cheese are generally considered an ideal growth medium for many fungal species, because such milk provides all important nutrients and conditions for fungal growth (Gulbe and Valdovska, 2014). The contamination of raw milk by fungiis influenced by the animal's physiological state breeding condition and the weatherthat may occur during milking, storage and other pre-processing activities (Callonet al., 2007).

The spoilage caused by fungal contamination of raw milk and cheese is manifested by the presence of many metabolic by-products, causing off-flavors, odors and visible changes in color and texture. Many yeasts growing in cheese resulting in yeasty tastes by producing alcohol and $\mathrm{CO}_{2}$, and some yeasts producing sulfides which causes egg odour. The presence of oxygen and low $\mathrm{pH}$ are selective media for moulds growth especially in cheese but some moulds can grow under low oxygen tension. Penicillium spp. and Cladosporium spp. are commonly moulds growing in vacuum-packaged cheeses(Ledenbach and Marshall , 2009). The characterization and identification of fungi in raw milk and cheese were based on phenotypic characteristics, and genotypic features. Also, the fungal count used as an index of sanitary quality of the milk and cheese (Moubasheret al.,2018).
The present study was planned to isolate and identify of fungal contamination in raw milk and some types of cheese samples.

\section{MATERIAL AND METHODS}

\subsection{Samples collection}

A total of 60 samples (20 raw milk ,20 processed cheese and 20 soft white cheese) were collected from different farms and supermarkets in Giza Governorate ,Egypt. All samples were collected and transferred aseptically in the icebox to the laboratory.

\subsection{Preparation of samples(APHA, 2001)}

The collected samples were prepared according to the technique recommended by APHA(2001).Twenty-five gm from each sample were carefully and aseptically homogenized in a blender with $225 \mathrm{ml}$ of sterile peptone water $0.1 \%$ to form a dilution of $1: 10$, from which tenth fold serial dilutions were accomplished up to $10^{-6}$.

\subsection{Mycological examination \\ 2.3.1. Isolation and counting of fungal spp.}

Dichloran Rose Bengal Chloramphenicol (DRBC) agar with chloramphenicol $0.05 \mathrm{mg} / \mathrm{L}$ )was prepared (ISO, 2008), then the medium was cooled in a water bath and maintained at a

\footnotetext{
* Corresponding author: Prof. Ashraf A. Abd El Tawab,Bacteriology, Immunology and Mycology Department, Faculty of Veterinary Medicine Benha University, Egypt
} 
temperature of $45^{\circ} \mathrm{C}$,then the media was dispensed in $15 \mathrm{ml}$ amounts in sterile Petri dishes and allowed to be solidified. Twenty-five grams from each sample were carefully and aseptically homogenized in a blender with $225 \mathrm{ml}$ of sterile peptone water $0.1 \%$ to form a dilution of $1: 10$, from which tenth fold serial dilutions were accomplished up to $10^{-6}$. Then, by sterile pipette, $0.1 \mathrm{ml}$ from each previously prepared dilutions were transferred to a single DRBC agar plate and distributed over the surface of the agar plate by sterile spreader. Then the inoculated plates were incubated in an inverted position at $25^{\circ} \mathrm{C}$ for 5-7days.

The isolated colonies were picked up from DRBC(ISO, 2008), into slope of Sabouraud dextrose agar, SDA (Oxoid $\mathrm{CM} 0041)$ agar and incubated at $25^{\circ} \mathrm{C}$ for $5-7$ days and then transferred on malt extract (MEA)(Oxoid CM0059) and Czapek yeast agar (CYA) plates (Pitt and Hocking, 2009) for identification. The inoculated plates were incubated at $25^{\circ} \mathrm{C}$ for one week.

\subsubsection{Identification of mould spp.}

The characterization of mould colonies was applied by microscopical examination and careful observation of the mould colonies according to Pitt and Hocking (2009)

\subsubsection{Identification of yeasts spp.}

Different yeast colonies were identified by,careful observation and microscopical examination according to Lodder and Kreger-van Rij (1970).

\section{RESULTS AND DISCUSSION}

Fungal contamination of raw milk and cheese occur as a result of wide distribution of fungal spores in un sanitized environment which lead to milk and cheese contamination during their production, transportation, manufacturing and storage. Also fungal contamination may be resulted from contaminated air, bad environment in some factories as, uncontrolled sterilization, use of low quality milk, unhygienic utensils, equipment, workers' clothes or recontamination after pasteurization, transportation or storage(Younis et al., 2016). Raw milk and cheese are generally considered an ideal growth medium for many fungal species, because of providing all important nutrients and conditions for fungal growth (Gulbe and Valdovska 2014).

In the current study a total of 60 raw milk and cheese samples (20 processed cheese , 20 soft white cheese and 20 raw milk samples ) collected from Giza Governorate, Egypt. were examined mycologicaly. The results showedin Table 1 revealed that, overall incidence rate of the mould in processed cheese, soft white cheese and raw milk samples were ; 18/20 (90\%), 6/20 (30\%) and 16/20 (80\%), respectively with mean mould counts $1.3 \times 10^{3} \pm 1.8 \times 10^{2}$ $\mathrm{cfu} / \mathrm{g}, 6.7 \times 10^{3} \pm 2.6 \times 10^{3} \mathrm{cfu} / \mathrm{g}$ and $5.9 \times 10^{3} \pm 1.3 \times$ $10^{3} \mathrm{cfu} / \mathrm{ml}$,respectively. The obtained results were nearly similar to El-Kestet al., (2015) who examined 30 samples from raw milk and 20 samples from processed cheese for mould contamination. They found that $90 \%$ of examined processed cheese samples and $76.6 \%$ of raw milk samples were positive for presence of moulds. Also Amer (2002) reported that the incidence of moulds in samples of soft white cheese was $95 \%$ of total examined samples. While EL-Bagoryet al. (2014) obtained higher results.
Delavenne et al. (2011) stated that fungal contaminated samples of cow milk contained high fungal diversity up to 15 species in a single sample, also a maximum of 4 or 6 different species were isolated from goat and sheep milks, respectively.

In the present study as shown in table 1 the predominant isolated genera in processed cheese were Aspergillus spp. (62\%), followed by Penicillium spp. (17.2\%) While, Eupenicillium spp. (10.3\%), Fusarium spp. (7\%) and Phoma spp. $(3.5 \%)$. The only two genera isolated in soft white cheese were Aspergillus spp. (83.3\%), Penicillium spp. $(16.7 \%)$. The most common isolated mould species from raw milk samples were Penicillium spp. (44.5\%), Aspergillus spp. (38.9\%) and Geotrichum spp. $(16.6 \%)$.These results are nearly similar to the results obtained by Nolwennet al. (2014) and Silva et al.(2015), who reported that the most isolated fungi in cheese and milk were Aspergillus spp., Penicillium spp., Geotrichum spp. and Fusarium spp. .WhileEl-Kestet al.(2015) revealed that the most predominant mould spp. in raw milk samples were Asperigellus spp. 10(33.3\%),Penicillium spp. $7(23.3 \%)$,Rhizopus spp. $10(33.3 \%)$ and other spp. in the same incidence 1(3.3\%) were Fusarium spp. and Mucor spp. while most predominant spp. in the processed cheese were Asperigellus spp.

Table 1 Incidence and statistical analytical results of mould isolated from the examined samples

\begin{tabular}{lllll}
\hline & $\begin{array}{l}\text { Total No. } \\
\text { of } \\
\text { examined } \\
\text { samples }\end{array}$ & $\begin{array}{l}\text { No. of } \\
\text { positive } \\
\text { samples }\end{array}$ & $\%$ & Mean $\pm \mathrm{SE}(\mathrm{cfu} / \mathrm{ml}$ or gm) \\
\hline $\begin{array}{l}\text { Processed } \\
\text { cheese }\end{array}$ & 20 & 18 & 90 & $1.3 \times 10^{3} \pm 1.8 \times 10^{2}$ \\
$\begin{array}{l}\text { Soft white } \\
\text { cheese }\end{array}$ & 20 & 6 & 30 & $6.7 \times 10^{3} \pm 2.6 \times 10^{3}$ \\
Raw milk & 20 & 16 & 80 & $5.9 \times 10^{3} \pm 1.3 \times 10^{3}$ \\
\hline \% According to total No. of examined samples for each type of samples.
\end{tabular}

In the present study the yeast contamination was not detected in processed cheese.This result was in coordinating with Egyptian Organization Standards (2005) who said that processed cheese should be free from any visible fungal contamination, but yeast contamination detected in soft white cheese and raw milk samples with incidence rate of $10 / 20(50 \%)$ and 16/20 (80\%); respectively(Table 5).The most predominant yeast species isolated from soft white cheese were Debaryomyces hansenii 14 (53.8\%), Pichia anomala $8(30.8 \%)$, Pichia membranafaciens $2(7.7 \%)$ and Sacharomyces cervisioe 2 (7.7\%).While, Candida tropicalis, Candida pseudotropicalis, Sacharomyces cervisioe and Torulopsis in the equal incidence of $2(14.3 \%)$ were detected in raw milk. Also, Rhodotorula 6 (42.8\%) detected in raw milk. These results agreed with El-Shazly, 2007 and Sayed et al., 2011 who examined mycologicaly 50 soft white cheese samples and showed that the incidence of yeasts in these samples was $60 \%$ and the more identification of those spp. may resulted from contaminated air, different season, bad environment in some factories as, uncontrolled sterilization, use of low quality milk, unhygienic utensils, equipment and storage. Seker (2010) said that the most common non-starter yeasts species which have been isolated from milk and cheeses were Candida intermedia, Candida lusitaniae, Candida parapsilosis, Candida rugosa, Cryptococcus curvatus, Issatchenkia orientalis, Pichia fermentans, Saccharomyces cerevisiae, Torulaspora delbrueckii and Yarrowia lipolytica. While, Spanamberg et al. (2014) examined 588 raw milk samples 
and revealed that the most common isolated yeast spp. were Candida spp. (70.00\%), Rhodotorula spp. (11.70\%),Trichosporon spp. (6.70\%), Geotrichum spp.
(5.00\%) Pichia spp. (5.00\%) and Cryptococcus spp. $(1.70 \%)$.

Table 2 Incidence of different mould genera isolated from different samples

\begin{tabular}{|c|c|c|c|c|c|c|}
\hline \multirow[b]{2}{*}{ Moulds } & \multicolumn{2}{|l|}{ processed cheese } & \multicolumn{2}{|l|}{ Soft white cheese } & \multicolumn{2}{|l|}{ Raw milk } \\
\hline & No of positive isolates & $\%$ & No of positive isolates & $\%$ & No of positive isolates & $\%$ \\
\hline Asperigellus spp. & 36 & 62 & 10 & 83.3 & 14 & 38.9 \\
\hline Penicellium spp. & 10 & 17.2 & 2 & 16.7 & 16 & 44.5 \\
\hline Eupenicillium spp. & 6 & 10.3 & 0 & 0 & 0 & 0 \\
\hline Phoma spp. & 2 & 3.5 & 0 & 0 & 0 & 0 \\
\hline Fusarium spp. & 4 & 7 & 0 & 0 & 0 & 0 \\
\hline Geotrichum spp. & 0 & 0 & 0 & 0 & 6 & 16.6 \\
\hline Total & 58 & 100 & 12 & 100 & 36 & 100 \\
\hline
\end{tabular}

\% calculated related to total number of isolates for each type of samples

Table 3 Incidence of Aspergillus species isolated from examined samples

\begin{tabular}{lllllll}
\hline \multirow{2}{*}{ Asperigellus Spp. } & processed cheese & \multicolumn{3}{l}{ Soft white cheese } & \multicolumn{2}{l}{ Raw milk } \\
\cline { 2 - 7 } & No. of positive isolates & $\%$ & No. of positive isolates & $\%$ & No. of positive isolates & $\%$ \\
\hline A.flavus & 24 & 66.7 & 4 & 40 & 6 & 42.8 \\
A.flocculosus & 2 & 5.6 & 0 & 0 & 0 & 0 \\
A.fumigatus & 0 & 0 & 2 & 20 & 0 & 0 \\
A.niger & 6 & 16.7 & 0 & 0 & 4 & 28.6 \\
A.sydowii & 2 & 5.5 & 0 & 0 & 0 & 0 \\
A.terreus & 0 & 0 & 0 & 0 & 4 & 28.6 \\
A.ustus & 0 & 0 & 4 & 40 & 0 & 0 \\
A.versicolor & 2 & 5.5 & 0 & 0 & 0 & 0 \\
Total & 36 & 100 & 10 & 100 & 14 & 100 \\
\hline \% calculated related to total number of isolates for each type of samples & & &
\end{tabular}

Table 4 Incidence of Penicillium spp. isolated from examined sample.

\begin{tabular}{lcccccc}
\hline Penicillium Spp. & \multicolumn{2}{c}{ processed cheese } & \multicolumn{5}{c}{ Raw milk } \\
\cline { 2 - 7 } & No. of positive isolates & $\%$ & No. of positive isolates & $\%$ & No. of positive isolates & $\%$ \\
\hline P.aethiopicum & 2 & 20 & 0 & 0 & 0 & 0 \\
P.aurantiogrseum & 0 & 0 & 2 & 100 & 6 & 37.5 \\
P.cammberti & 2 & 20 & 0 & 0 & 0 & 0 \\
P.citreonigrum & 2 & 20 & 0 & 0 & 0 & 0 \\
P.crustosum & 0 & 0 & 0 & 0 & 6 & 37.5 \\
P.digitatum & 0 & 0 & 0 & 0 & 2 & 12.5 \\
P.implicatium & 2 & 20 & 0 & 0 & 0 & 0 \\
P.oxalicum & 0 & 0 & 0 & 0 & 2 & 12.5 \\
p.simplicissimum & 2 & 20 & 0 & 0 & 0 & 0 \\
Total & 10 & 100 & 2 & 100 & 16 & 100 \\
\hline \% & 2 & 2 & & &
\end{tabular}

\%calculated related to total number of isolates for each type of samples

Table 5 Incidence and statistical analytical results of yeasts isolated from examined samples

\begin{tabular}{lcccc}
\hline Type of samples & Total No. of examined samples & No. of positive samples & $\%$ & Mean \pm SE (cfu/ml or gm) \\
\hline Processed cheese & 20 & 0 & 0 & 0 \\
Soft white cheese & 20 & 10 & 50 & $5 \times 10 \pm 1.3 \times 10$ \\
Raw milk & 20 & 16 & 80 & $7.6 \times 10^{2} \pm 2.4 \times 10^{2}$ \\
\hline
\end{tabular}

$\%$ According to total No. of examined samples for each type of samples

Table 6 Incidence of yeast species isolated from examined samples

\begin{tabular}{lcccccc}
\hline Yeast Spp. & processed cheese & Soft white cheese & \multicolumn{2}{c}{ Raw milk } \\
\cline { 2 - 7 } & No. of positive isolates & $\%$ & No. of positive isolates & $\%$ & No. of positive isolates & $\%$ \\
\hline Candida tropicalis & 0 & 0 & 0 & 0 & 2 & 14.3 \\
Candida pseudotropicalis & 0 & 0 & 0 & 0 & 2 & 14.3 \\
Debaryomyceshansenii & 0 & 0 & 14 & 53.8 & 0 & 0 \\
Pichia anomala & 0 & 0 & 8 & 30.8 & 0 & 0 \\
Pichia membranafaciens & 0 & 0 & 2 & 7.7 & 0 & 0 \\
Rhodotorula & 0 & 0 & 0 & 0 & 6 & 42.8 \\
Sacharomyces cervisioe & 0 & 0 & 2 & 7.7 & 2 & 14.3 \\
Torulopsis & 0 & 0 & 0 & 0 & 2 & 14.3 \\
Total & 0 & 0 & 26 & 100 & 14 & 100 \\
\hline \%calculated related to total number of isolates for each type of samples & & &
\end{tabular}




\section{CONCULSION}

In conclusion, fungal contamination of raw milk and cheese samples collected from markets in Giza Governorate, Egypt, was clearly observed in this study indicating unsatisfactory Hygienic measures during milk production, handling and cheese manufacture. The most prevalent mould species were Aspergillus and Penicillium spp. The growing fungi may represent potential health hazards for consumers. Thus, strict hygienic measures should be adoptedduring milk production handling, cheese processing and storage and the end product should be complied with the Egyptian standards.

\section{REFERENCES}

1. Amer, A. A., 2002: Safety and quality of butter and cheese through mycological criteria. Ph.D. Thesis. Fac. Vet. Med., Alex. Univ. Egypt.

2. American Public Health Association (APHA), 2001: Compendium of methods for the microbiological examination of foods. 4thEd. Eds. Downes P. and K. Ito. Sheridan Books Inc.,Washington D.C., USA.

3. Callon, C., Duthoit, F., Delbes , C., Ferrand, M., Le Frileux, Y., De Cremoux, R., Montel, M.C., 2007. Stability of microbial communities in goat milk during a lactation year: approaches. Systematic and Applied Microbiology, 30, 547 560.

4. Delavenne, E., Mounier, J., Asmani, K., Jany, J.L., Barbier, G., Le Blay, G., 2011. Fungal diversity in cow, goat and ewe milk. International Journal of Food Microbiology $151,247-251$.

5. Egyptian Standards (2005): Processed cheese. Part 2: Processed cheese paste Organization for Standardization and Quality Egyptian Control.Standard number 999-2/2005

6. EL-Bagory, A.M., Amal, E.M., Hammad, A.M., Salwa, A.D., 2014. prevalence of fungi in locally produced cheese and molecular characterization of isolated toxigenic molds. BenhaVet. Med. Journal 27(2), 9-20.

7. El-Kest, M., El- Hariri, M., Khafaga, E., Nagwa, I.M., Refai, M.K., 2015. Studies on contamination of dairy products by aflatoxin M1 and its control by probiotics. Journal of Global Biosciences 4(1), 1294- 1312
8. El-Shazly S.M., 2007. studies on enterobacteriaceae, yeasts and moulds in milk and some dairy products. Ph.D. Thesis Fac. Vet. Med., Minufiya Univ., Sadat branch

9. Gulbe, G., Valdovska, A., 2014. Diversity of Microscopic Fungi in the Raw Milk from Latvian Organic farm. Proc. Latv. Univ. Agr., 31(1), 46-53

10. Ledenbach, L.H., Marshall, R.T., 2009. Microbiological Spoilage of Dairy Products. Compendium of the microbiological spoilage of food and beverages. Pp.41-67

11. Lodder, J., Krger-Van Rij, N.J.W., 1970. The Yeasts: A taxonomic Amsterdam. North Holland Publishing.

12. Moubasher, A. A.H., Abdel-Sater, M.A., Soliman, Z.S.M. 2018. Yeasts and filamentous fungi associated with some dairy products in Egypt. Journal de MycologieMedicale 28(1),76-86.

13. Nolwenn, H., Vasseur, V., Monika, C., Jérôme, M., Jean-Luc, J., Georges, B., Emmanuel, C., 2014. Filamentous Fungi and Mycotoxines in Cheese. Comprehensive Reviews in Food Science \& Food Safety 13(4), 437- 456.

14. Oxoid Manual 1990. Culture media, ingredients and other Laboratory services. $6^{\text {th }}$ Ed. Published by Unipath Limited, Wade Road. Basinga stoke Hampshire, R.G. 24OPW, England.

15. Pitt, J.I., Hocking, A.D., 2009. Fungi and Food Spoilage book, $3^{\text {rd }}$ Edition.Springer Science,Business Media,LLC

16. Sayed, M., Abdel-Hameid, A., Walaa, S.H., 2011 Microbiological evaluation of some Egyptian white soft cheese. BVMJ, 1, 1-6.

17. Seker, E., 2010. Identification ofCandidaspecies isolated from bovine mastitic milk and their haemolytic activity in vitro in western turkey. Mycopathologia169, 303-308

18. Silva, J. L., Aparecido, C.C., Hansen, D., Pereira, T.A.M. Felicio, J.D., Goncalez, E., 2015. Identification of toxigenic Aspergillus species from diet dairy goat using a polyphasic approachCentro de CienciasRurais, Universidade Federal de Santa Maria.Ciencia Rural 45(8),1466-1471.

19. Spanamberg, A., Fraga, C.F., Ferreiro, L., Aguinsky, M.S., Sanches, E.M.C., Roehe, C., Lautert, C., Santurio, J. M., 2014 Yeasts in the raw ewe's milk. Acta Scientiae Veterinariae 42,1236-1240

20. Younis, G., Ibrahim, D., Awad, A., El-Bardisy, M.M., 2016 Determination of aflatoxin $\mathrm{M}_{1}$ and ochratoxin $\mathrm{A}$ in milk and dairy products in supermarkets located in Mansoura City, Egypt. Advances in Animal and Veterinary Sciences 4(4), 114 121 